\title{
萌发的混合景观与新乡土景观 \\ EMERGING HYBRIDITY AND \\ THE NEW VERNACULAR LANDSCAPE
}

丹尼·卡尔森 领域事务所创始人

Dane CARLSON Founder of REALMS

3315 LaSalle Avenue, Michigan City, IN 46360, USA

danegcarlson@smail.com

领域事务所的景观实践包括设计、研究、制图及建造, 其所 涉及的内容立足于多领域交汇处, 神圣与庸常、设计学与人 类学、场地尺度与全球尺度在其作品中共存。更多关于事务 所的信息，请访问http://realms.work/。

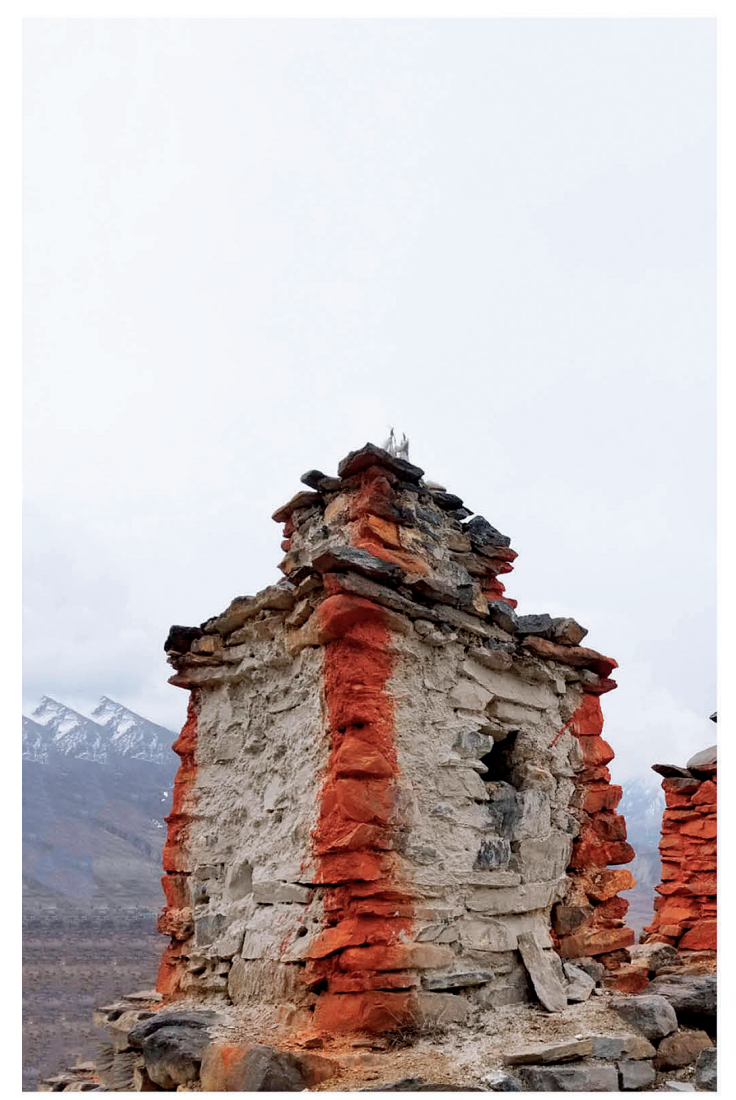

REALMS is a landscape practice engaged in design, research, mapping, and making. Its work is sited at the intersection of many realms: sacred and profane, design and anthropology, place-specific and global. For more information, please visit http://realms.work/.

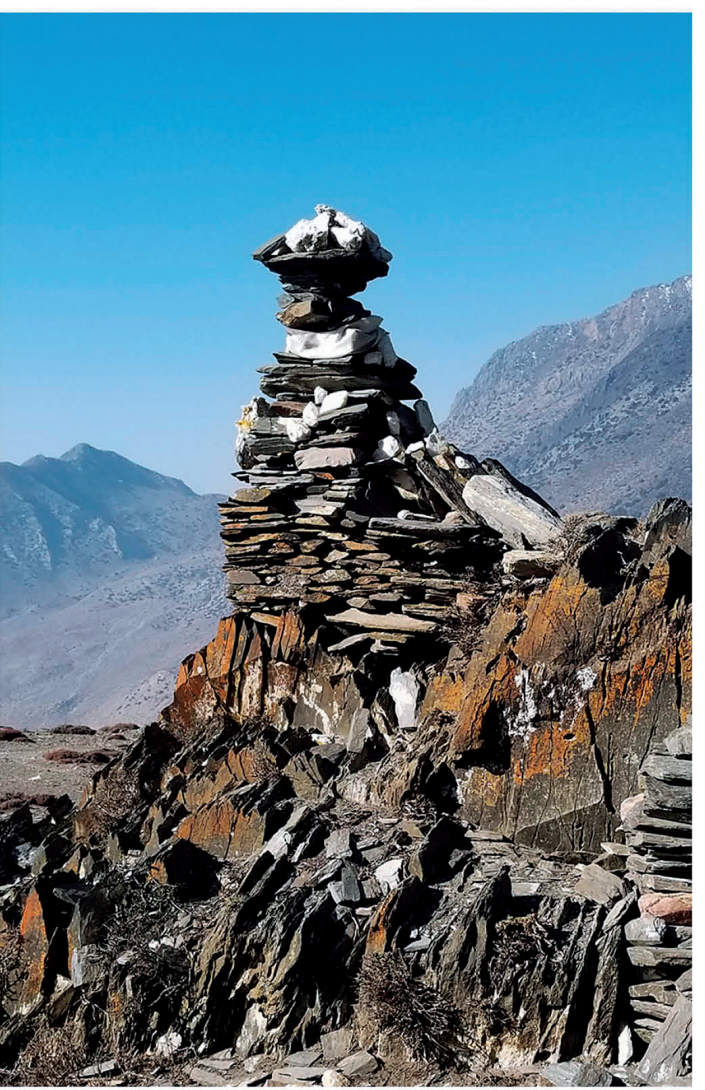

遍布下木斯塘地区的曲丹佛塔

Chhortens throughout Lower Mustang

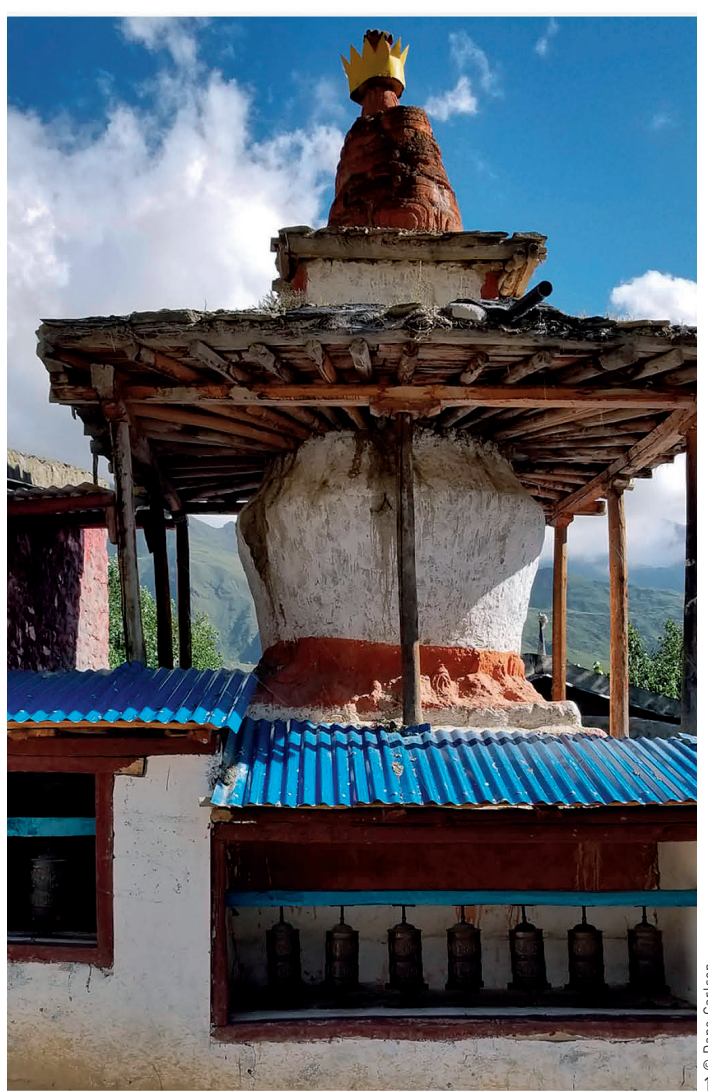


https://doi.org/10.15302/J-LAF-2018031

收稿时间 RECEIVED DATE / 2018-05-02

中图分类号 / TU98, C91

文献标识码 / B
乡土景观处在永恒的变化之中, 是承 载着 “当地风俗、具有实际效用的环境适应 性, 以及不可预知的流动性” 的景观 ${ }^{[1]}$ 。然 而, 与景观设计学科语境中的 “生态学” 及“都市主义”这两个常被讨论的议题不 同，乡土性从杂乱的现实世界以及人们日常 生活的点滴中生发。加雷斯. 多尔蒂重新 将“人”的角色引入对景观的讨论之中,

“景观由土地、栖居于土地之上的人, 以 及二者之间的关系所组成。”[2]约翰. 布林 克霍夫. 杰克逊没有采用流动性或系统性来 描述乡土景观, 而是从 “美” 的角度对其进 行阐释——“我们在乡土景观中看到的美即 是我们所共有的人性形象: 勤勉地劳作、顽 强地葆有希望, 彼此包容、互助友爱。”[1] 乡土景观由人性和人的精神动力共同创造, 它与生态流及生态系统等生态学思想密不可 分。随着韧性环境建造实践的不断推进, 乡 土景观必须摆脱其目前在景观学术研究中所 处的边缘地位, 强调自身作为景观实践必要 平台的价值。

在尼泊尔的木斯塘地区, 生命的延续 以具有实际效用的环境适应性为特征的乡土景观, 必须 实现从学术议题到设计实践的角色转变。乡土性是动态的,

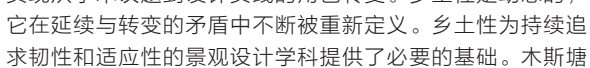
求韧性和适应性的景观设计学科提供了必要的基础。木斯塘 经历经济、基础设施, 以及人口结构巨变所带来的冲击。为 了应对不断出现的延续与断层问题, 这里的景观正在被重塑 为一种混合景观, 即一种新乡土景观。在延续与转变的碰撞 中, 新的资源与机会不断产生, 由此衍生的温合实践必将继 续演进。 续演进。

乡土景观; 混合景观; 尼泊尔; 延续与转变; 能动性; 适应 性响应

\section{ABSTRACT}

The vernacular landscape, defined by pragmatic adaptation, must shift from subject of scholarship to realm of design operations. The vernacular is dynamic, constantly redefined at the intersections of continuity and change. It provides the necessary foundations for a discipline expanding in pursuit of resiliency and adaptive response. The landscape of Nepal's Mustang district, peripheral to the Nepali state for most of its history, is being shaken by seismic economic, infrastructural, and demographic shifts. In response to emerging continuities and discontinuities, its landscape is being remade as a hybrid andscape, a newvernacur. This practice of hybridization must continue to evolve where new resources and opportunities
mandscape, a new vernacular. This practice of hybridization must continue to evolve where new resources and oppor
emerge at the intersections of continuity and change. KEY WORDS

Vernacular Landscape; Hybridity; Nepal; Continuity and Change; Agency; Adaptive Response

刘姝 陆小璇

TRANSLATED BY Shu LIU Xiaoxuan LU
至今仍与土地及土地利用周期密切相关。 成群结队的驮畜将粪肥从高地牧场运往农 田（图2），自然的馈赠供养着人们的日常 生活（图3），而村民通过复耕仪式祭拜的 土地守护神也保护着当地的农田（图4)。 然而, 如今的木斯塘正处于延续与转变的矛 盾状态之中，在这一交汇碰撞的节点，一种 新的景观形式应运而生一一是延续传统, 还 是做出改变? 乡土景观正悄然发生着改变。 无数的房屋和农场因村民外迁而变得空空如 也, 只有来自尼泊尔其他地区的佃农居住在 这里。尽管北部边境的封闭使得牲畜大规模 迁徙的范围大大缩小, 但放牧仍然是木斯塘 居民日常生活的重要组成部分。古老的村庄 随着冰川河的消失而不得不迁址。当祖辈相 传的知识不再传递给年轻一代, 土地复耕的 传统也逐渐丢失。与此同时, 苹果树的大量 繁殖为当地许多家庭提供了新的经济来源。 道路建设也如火如茶, 其中包括一条连接中 国和尼泊尔的主要公路。

当地的这些巨变无论从意向到执行,
初衣都很简单。例如, 道路建设对木斯塘产 生了诸多影响, 尽管它的初衷是改善人们的 生活质量, 但实际情况却复杂得多。最近的 研究表明, 道路建设加剧了社会经济的不平 等。土地所有者和富人能够利用新经济体进 一步发家致富, 而边缘群体却无法以同样的 方式积累财富, 相反, 他们的生活被这些并 不可靠的基础设施和交通运输网所支配, 之 前遍布此地的家族网络体系也被逐渐击溃。 在穆克提纳斯山谷, 通往当地朝圣圣地的道 路已变为公路, 虽然交通因此更加便捷, 但 它同时创造出一系列问题不断的混合景观 （图5）。设计欠佳的基础设施导致道路上 的雨水和融雪直接流入邻近的苹果园, 造成 了严重的地表冲刷; 周边村庄的牧羊人时而 沿公路放牧, 时而穿越公路, 牲畜很容易受 到公共汽车和吉普车的伤害; 公路建设过程 中产生的废弃物和用罢的空沥青桶堆放在路 边; 除了一长串沿路开设的商店和招待所之 外, 再难发现公路与周边环境的潜在互动关 系。尽管这些景观的成因并不复杂, 但其产 生的后果却涉及社会生活的方方面面。

为了更好地利用存在于景观的延续与转 变中的潜在的生发关系, 上述这些碎片化的 景观干预需要被重新构想。对这种潜在生发 关系的探究, 应起始于改变发生之前或发生 之时, 而非在改变发生之后。也就是说, 集 延续与转变于一身的混合景观的生成, 必须 在一种意于在知识、实践、资源和基础设施 之间创造新连接的目标指导下展开。混合景 观需要去弥合因基础设施建设、社会经济差 异、人口和气候变化而产生的不连续性。一 种新的景观形式一一新乡土景观就此产生, 其建立在当地资源之上, 传承着深刻的记忆 与本土知识, 能够应对气候限制和不断变化 的现实世界。

面对边疆地区所经历的快速变化, 这种 新乡土景观已经开始呈现出独特的新形式。 可用资源不经意间的微小变化也会对当地人 的日常生活产生重大影响。比如在木斯塘地 区的柯永伽村, 一个17岁的牧羊少年长期 受到羊群饮水问题的困扰, 他要么需要深入 到陡峭的峡谷中汲水, 要么需要挨到晚上回 

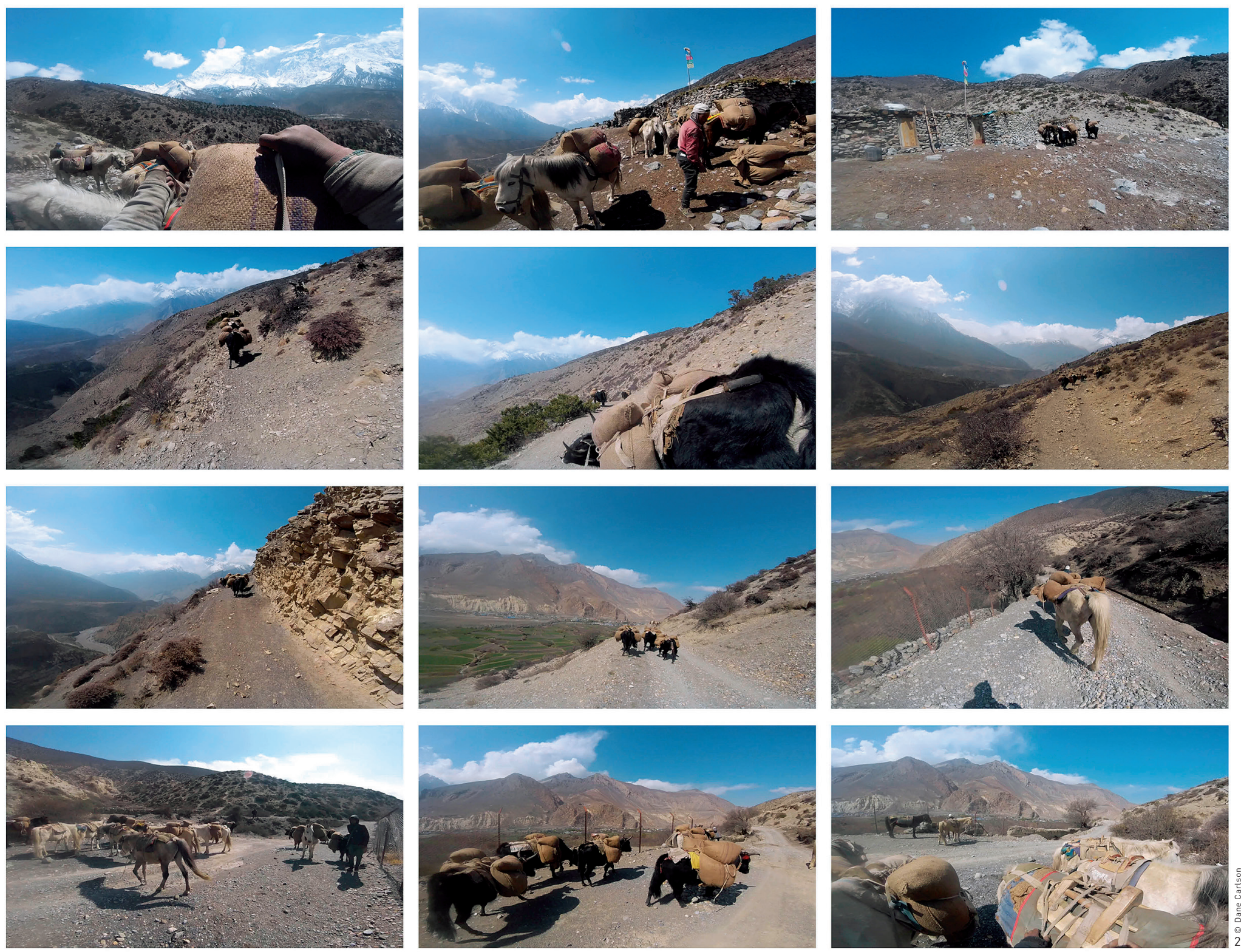

到村子的河塘才能给羊群喂水。而在村里安 装了供水管道之后, 他利用从管道中渗漏出 的水, 挖出了一系列可供羊群饮水的小水塘 (图6)。

采用全新材料建造的曲丹佛塔同样体现 了乡土景观的改变。用于宗教仪式的基础设 施遍布整个木斯塘, 其中最具代表性的就是 曲丹佛塔, 佛塔样式众多且每一种都代表着 不同的含义（图7）。一些曲丹佛塔用于纪 念逝者或作为各处圣地的标志性建筑, 而另
一些则建在村庄与神域的交界处。但时至今 日, 许多木斯塘的年轻人对于这些含义已一 无所知。建在交界地段的曲丹佛塔通常供奉 着圣三部主的佛像, 他们代表着藏传佛教的 三位保护者。这些美丽的曲丹佛塔由土砖建 成, 使用色彩明亮的粘土着色 (图1)。佛 塔的每一个建造步骤都为当地所特有, 其建 造方法不以造型精准为目标, 而是充满了随 性与诗意。粘土通常从上木斯塘和下木斯塘 的悬崖峭壁中精心采集而来, 其中包括达柯
2. 杜立巴人和赶马人将山 羊粪肥从高地牧场运往 农田和苹果园。

2. Dzopa and horse drivers carry goat manure from high pastures to village fields and apple orchards. 

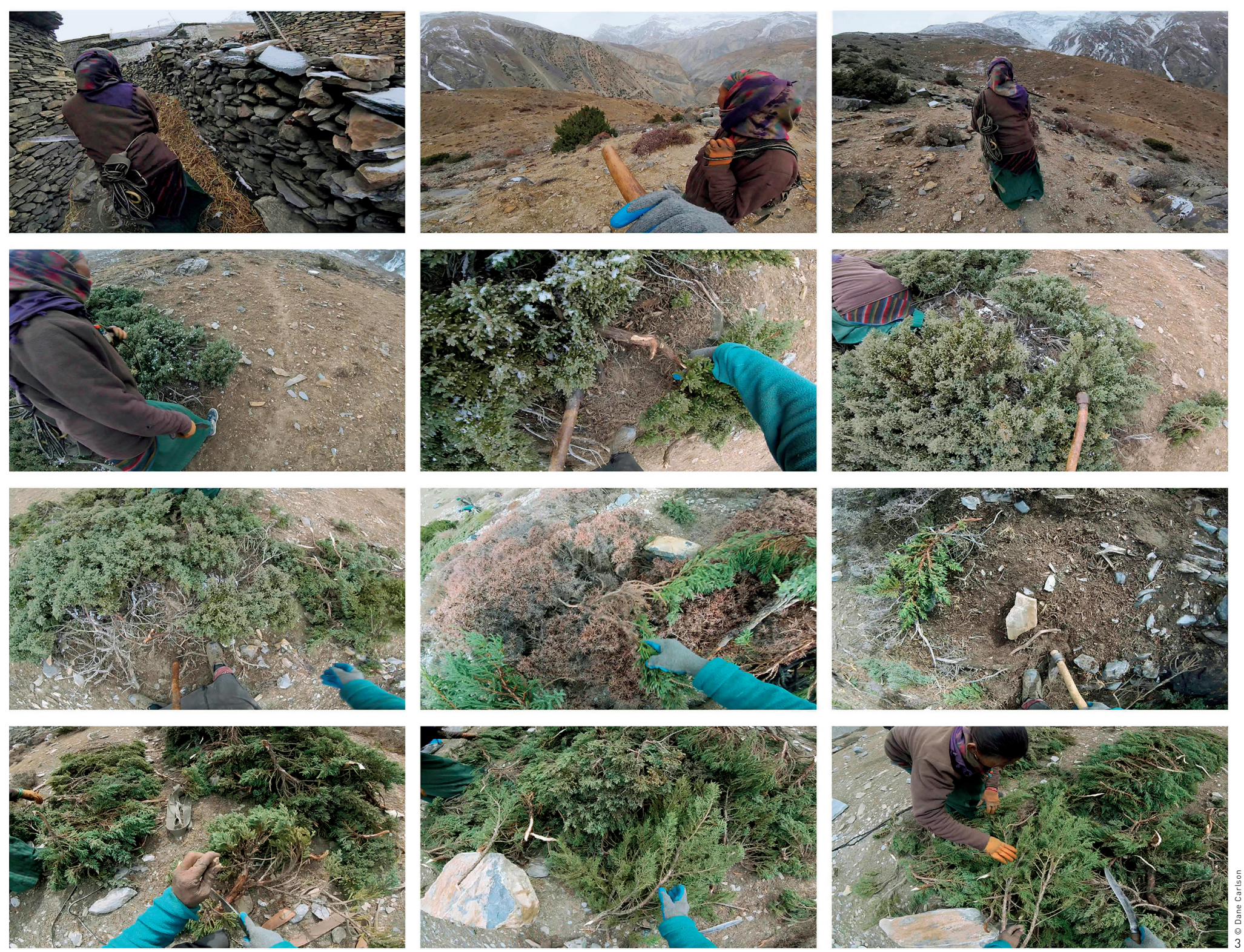

马的红色峭壁。据传, 是莲花生大士杀死的 妖魔的血液染红了这处峭壁, 因此, 曲丹佛 塔运用红色粘土着色象征着达摩宗教优于先 前占统治地位的萨满教。这些佛塔记录着时 间的流逝, 任凭雨水与融雪在其上冲刷留下 岁月的痕迹。

然而现在, 越来越多的曲丹佛塔改由混 凝土建造（图8）。这大大减少了每年的重 修费用和相应的仪式花销。虽然混凝土材料 可能不那么浪漫, 但它被视为一种全新的材
料。由于村庄里的人口数量持续下降, 且原 住人口逐渐被外来佃农所替代, 所以关于曲 丹佛塔的意义、历史和仪式等相关知识正面 临失传。同时, 劳动力短缺也是混凝土建造 盛行的原因之一：使用混凝土材料和商店出 售的油漆仅需很少的维护, 并且能够有效节 约建造时间。混凝土的防水效果也更好, 它 能够有效保护存放在佛塔中的物品, 例如来 自有威望的喇嘛或已故村民的书籍和衣物。 在开穆卡尔村, 4 组圣三部主的佛像分别在

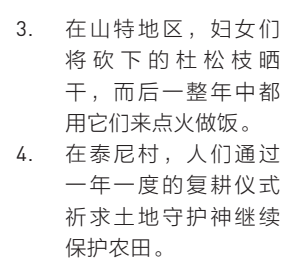

3. In Santak, women cut juniper branches, which will be dried and used to start cooking fires throughout the year. In Thini, field protectors known as Kodjang are renewed through an annual regeneration and remaking ritual. 

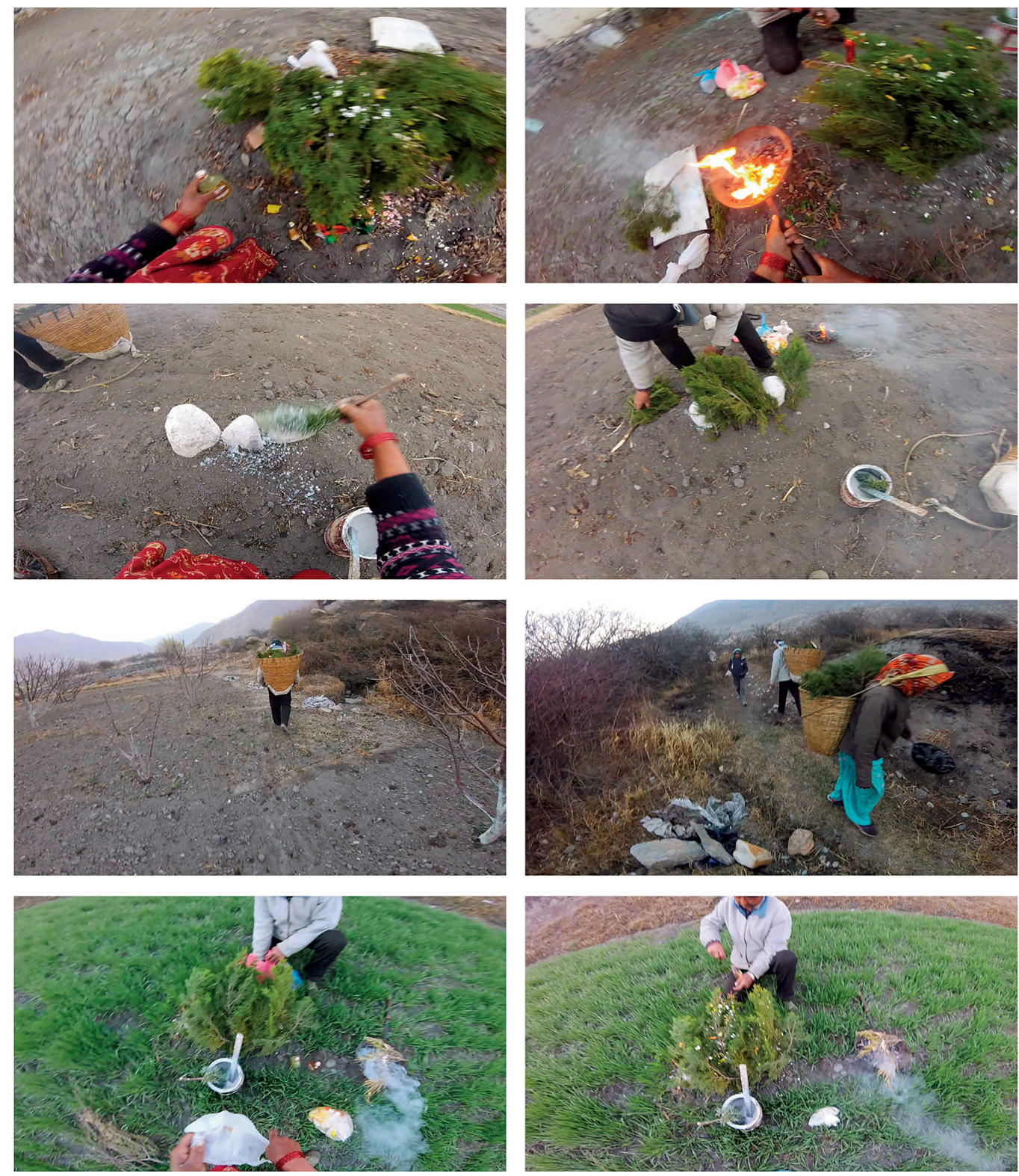

4个主要方位上守卫着村庄。2017年, 这 些泥塑与石塑的曲丹佛塔被拆毁, 取而代之 的是新建的混凝土佛塔, 佛塔上涂有白色、 蓝色和黄色三种颜色，而选择这些颜色仅仅 是因为当时正好只能找到这三种颜色。尽管 发生了上述变化, 曲丹佛塔的宗教力量并未 改变, 它们在宗教仪式中不断复兴, 继续发 挥着保护效力。但随着知识在传承之中的减 少以及宗教仪式感在混凝土建造过程中的退 化，曲丹佛塔的保护效力似乎难免随时间流
逝而逐渐衰退。如果曲丹佛塔终将衰落, 那 也绝不仅仅是因为使用了新材料, 其根源在 于本土知识与乡土记忆的丧失。

对延续与转变的混合应具有生发性而非 破坏性一一这对于人口急剧变化的边缘群体 尤为重要。既成事实是, 在富人与土地所有 者外迁或进行新经济体创业的同时, 其他人 群的生活依然与这片土地及其上所发生的剧 变息息相关。边缘群体有限的生活保障正被 逐年减少的降雨量所动摇。因此, 景观设计
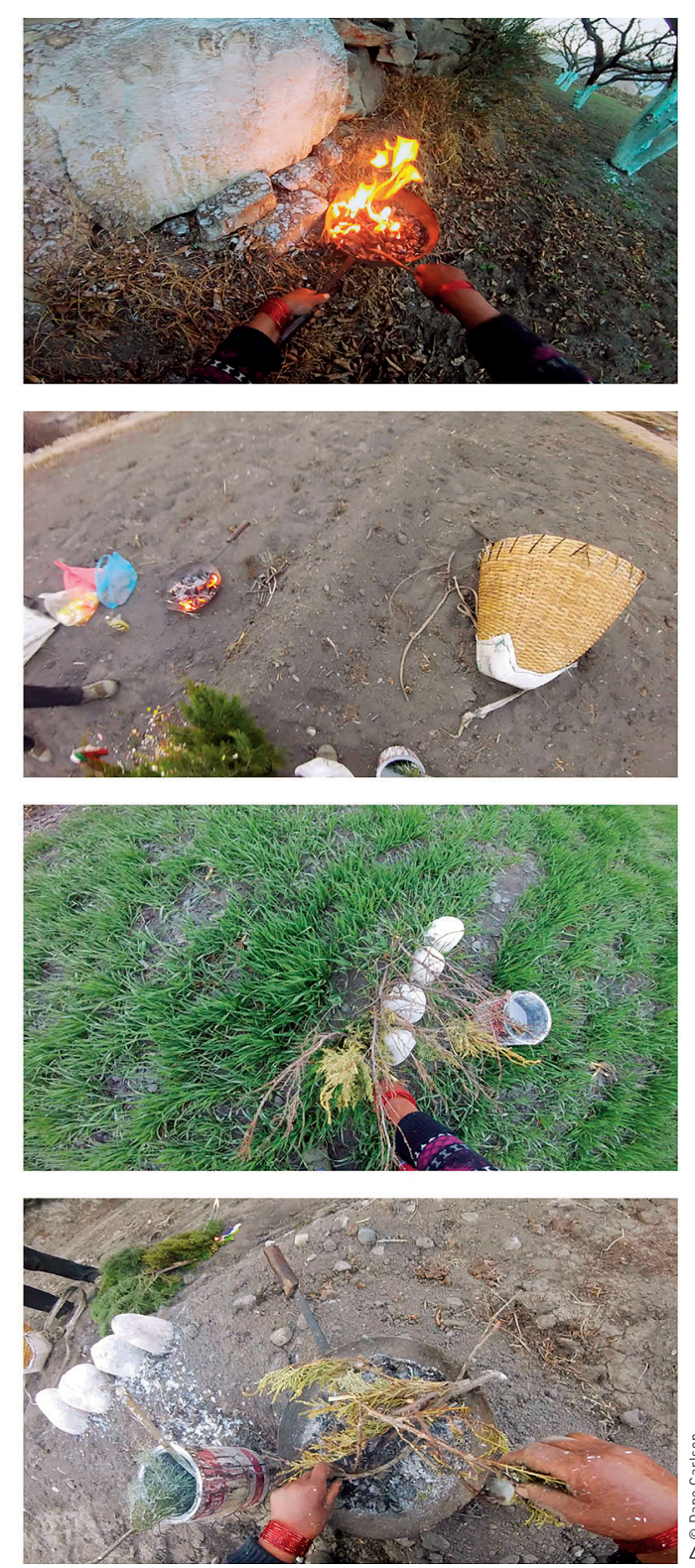

师有能力亦有责任塑造一种基于新乡土景观 设计原则、且能够与当地居民共同营造的新 景观。

在整个木斯塘地区, 牲畜仍然是当地人 维持生计的重要组成部分。牧民们依照季节 变化带着牲畜穿梭于不同的牧场, 他们通常 会连续几个月蜗居在遍布于村庄高地的石棚 里，以免浪费宝贵的时间在村落和高地牧场 间不停往返（图9）。但这些牧民通常来自 木斯塘以外的其他地区, 很少在木斯塘停留 
超过几年。他们属于较低的种姓, 其所饲养 的牲畜也很少为自身所有。面对降水模式的 变化和由此导致的饲料匮乏, 他们的生计越 来越缺乏保障。尽管牧民们在放牧过程中主 动地塑造着景观, 但是他们塑造景观的能动 性及潜力却常被忽视。而在新乡土景观中, 牧民不仅仅是被动的旁观者, 更扮演着环境 管理者和塑造者的角色（图10)。

这种新乡土景观由知识、含义、实践和 实体景观本身共同塑造。新乡土景观仍被人 们对于这片土地的深刻认知所驱动, 包括土 地的本来面貌、土地所提供的资源, 以及土 地正在经历的变化。但是这些认知可以被扩 展以涵盖更广泛的科学知识, 从而为牧民提 供塑造景观和基础设施所必备的实践工具。 比如, 面对降雪和降雨量愈发不确定的情 况, 牧民们建成了一种通过保持环境湿度来 改善微气候的新型基础设施。这些基础设施
具有多重效用, 包括遮阴、防止风干、形成 可转化为水库的雪堤, 为牧民和牲畜提供庇 护所, 以及为牧民提供从高处俯瞰牧群的瞭 望塔。虽然大规模的人口外迁与不断增加的 畜牧成本可能使放牧这一形式逐渐消失, 但 这些最初为方便放牧而建造的基础设施可以 继续发挥新的作用。比如, 它们提供的水源 可以促进被烧毁的杜松林重新生长, 或者作 为逃避雪豹追赶的野鹿的栖息之所一一这是 目前大多数环境保护工作的重点。最重要的 是, 在上述场景中, 牧民均可积极发挥其能 动性以塑造景观。

新乡土景观的出现是对存在了上干年的 适应性景观的延续。它由人们对复杂日常 生活的反应、人类的能动性, 以及人类所 拥有的知识所驱动。在适应性响应与㓞性 建造日益重要的世界里, 这就是景观的未 来。LAF
5. 遍布穆克提纳斯公路的 山羊尿显示出新兴的公 路建设和传统牧羊活动 之间的交叠。

6. 在索朗拉附近, 安装混 乱的输水管道一旁挖出 了新水塘。

5. The Muktinath road is covered in goat urine, a manifestation of the overlaps between new road construction and continuing goat herding practice.

6. New ponds constructed under a poorly installed pipe near Thorong La

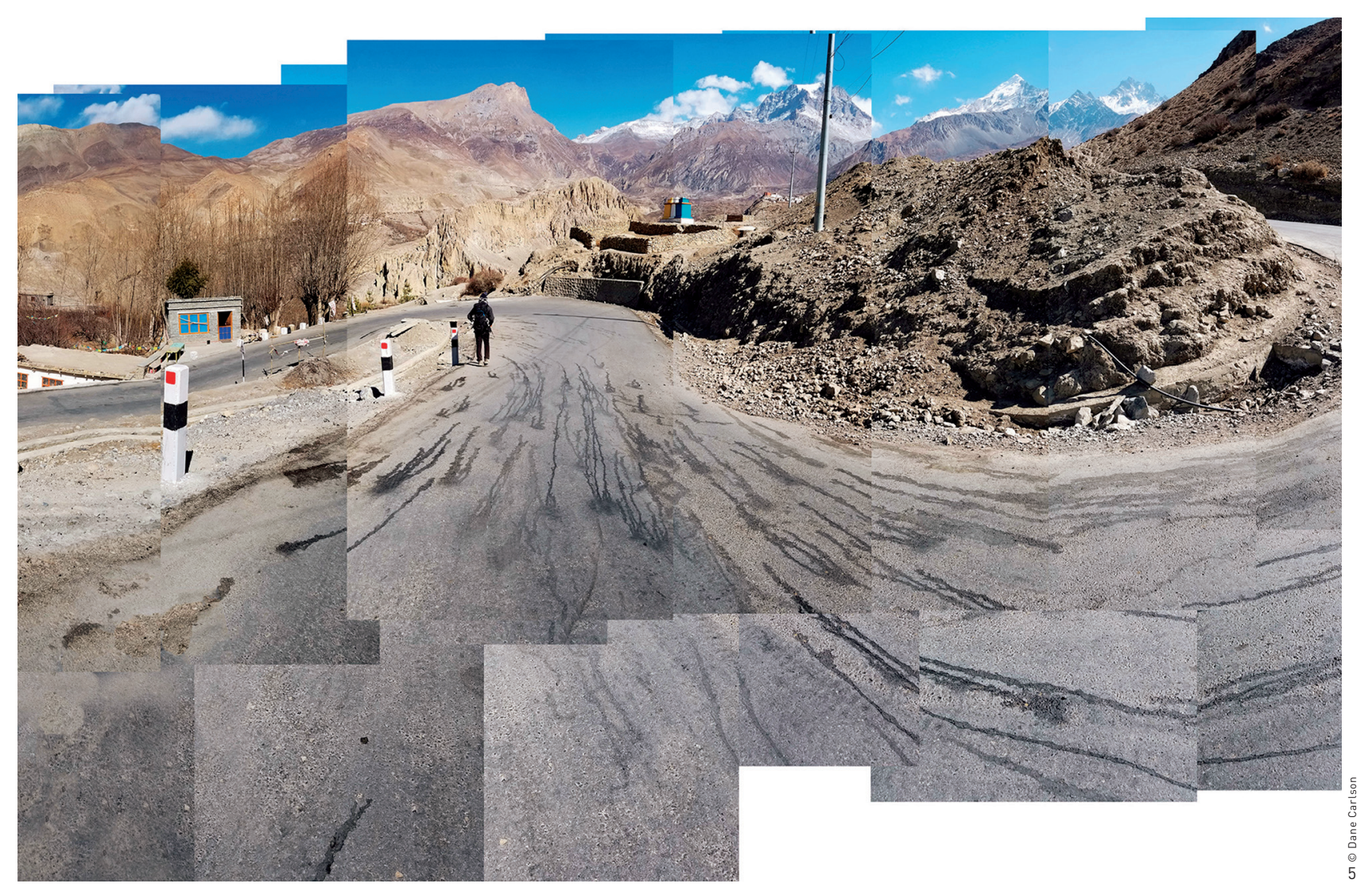



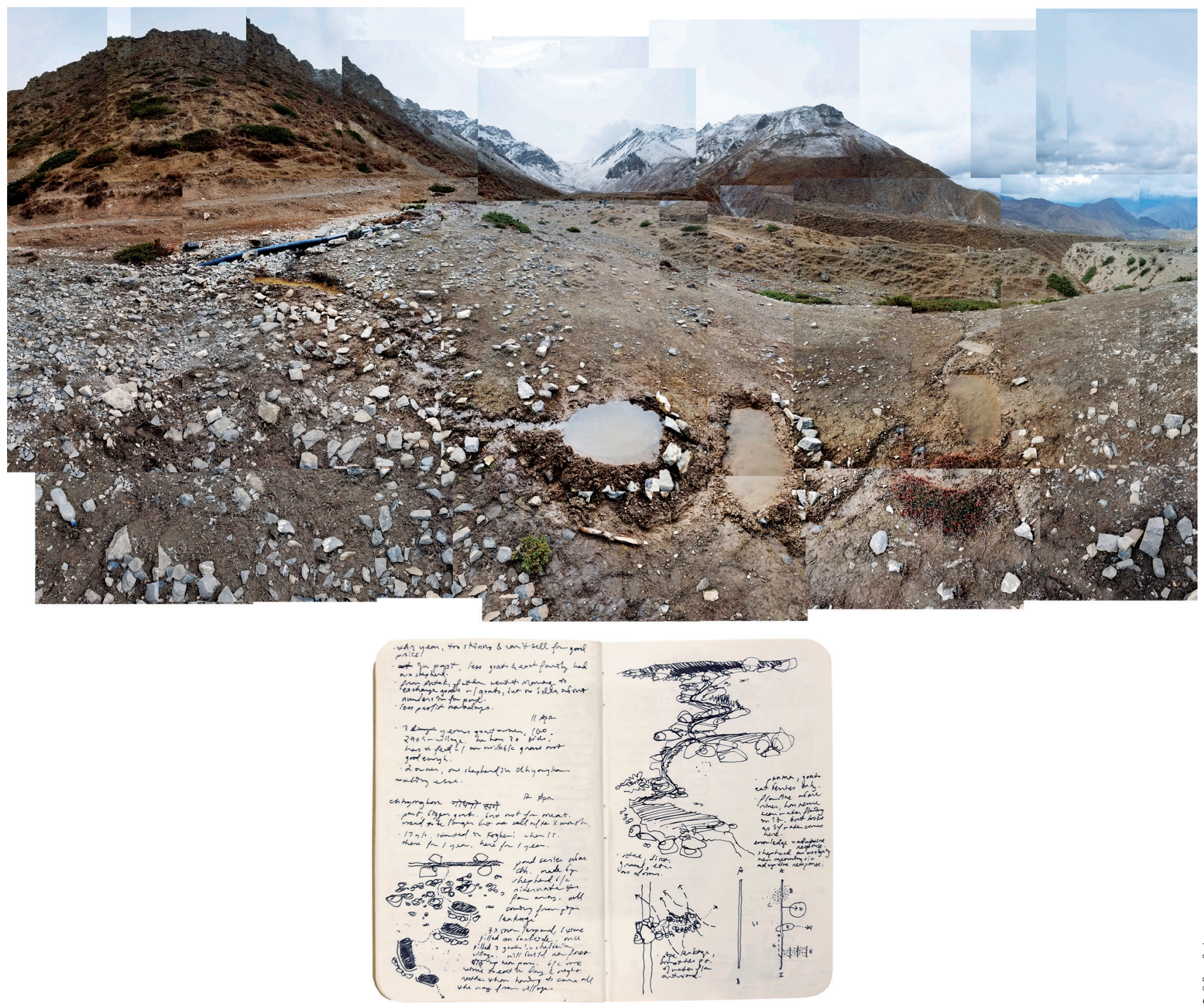

The vernacular landscape is perpetually dynamic, identified with "local custom, pragmatic adaptation to circumstances, and unpredictable mobility" ${ }^{[1]}$. But unlike the dynamism of ecologies and urbanisms so common to landscape architecture discourse, the vernacular emerges from the chaos of human realities and the grittiness of daily life.
Gareth Doherty returns landscape to the human, saying simply "landscape comprises the land and the people who inhabit the land, as well as the relationships between them." ${ }^{[2]}$ John Brinckerhoff Jackson described the vernacular not in terms of flows or systems, but beauty - "the beauty that we see in the vernacular landscape is the image of our common humanity: hard work, stubborn hope, and mutual forbearance striving to be love. ${ }^{[1]}$ It is simultaneously created by humanness and dynamism, inseparable from the flows and systems of ecological thought. As we continue to embrace the practice of resiliency building, the vernacular landscape must become more than a 

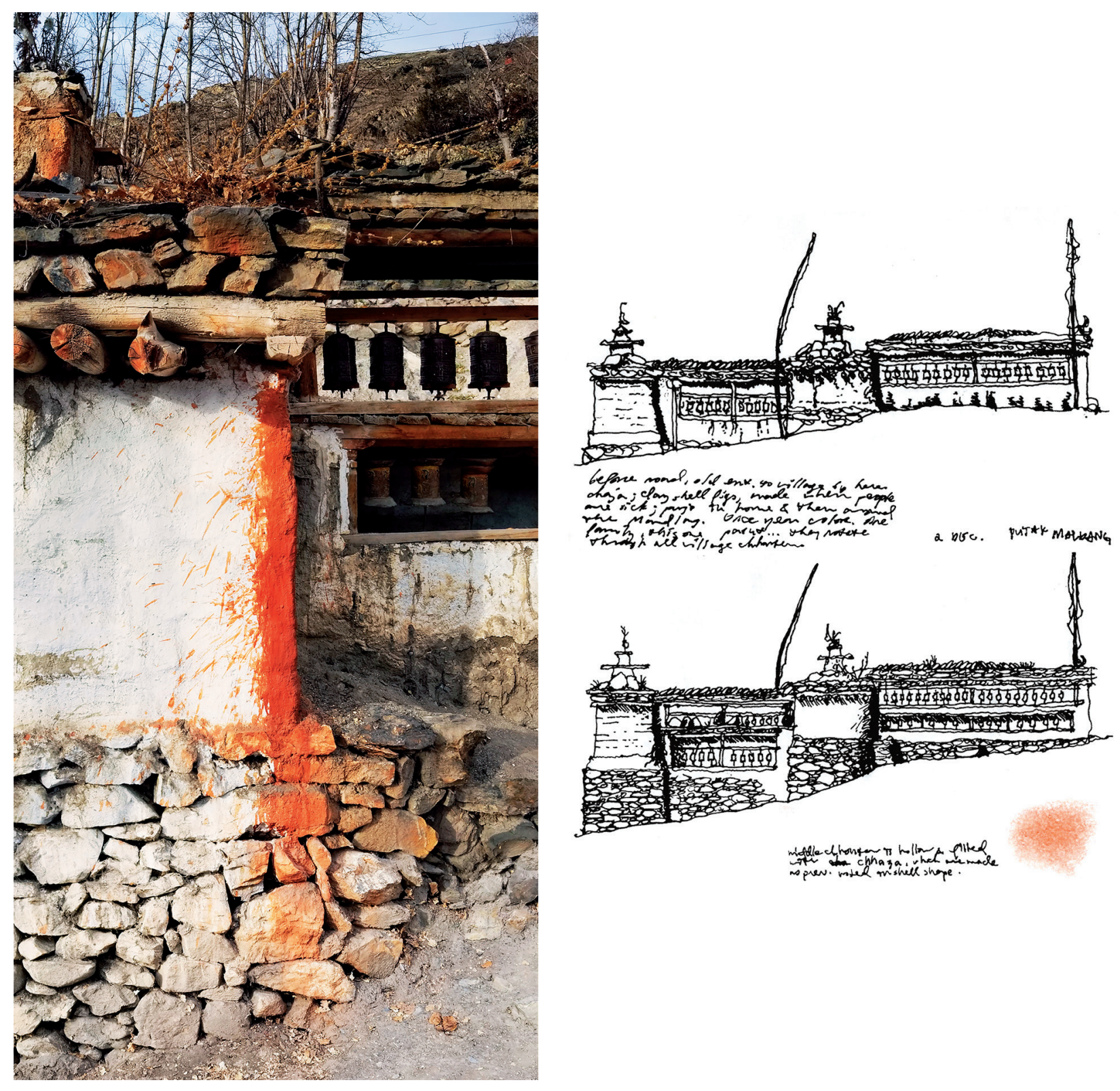

peripheral point of landscape scholarship. It is a necessary platform for action.

Nepal's Mustang district remains dominated by lives intimately tied to the land and its cycles. Caravans of pack animals carry manure from high pastures to fields (Fig. 2), the activities of daily life are supported by products harvested from the landscape (Fig. 3), and fields are protected by rituals of renewal (Fig. 4). But Mustang finds itself at the meeting of continuity and change. At this point of hybridity, a new landscape is emerging. It is simultaneously pulled between these two poles and reformed at their points of intersection. Outmigration has left countless houses and farms empty, only to be occupied by tenant farmers from across Nepal. Large-scale movements of livestock remain important components of daily life despite being severely curtailed by a closed border to the north. Villages have been relocated as their glacial meltwater streams disappear. Patterns of ritual regeneration are lost as knowledge is not transferred to younger generations. The proliferation of apple farming provides many families with a new cash crop. Road construction includes a major highway to connect China and Nepal.

Much of these radical changes are onedimensional in intention and execution. Road building is a prolific practice in Mustang, and though it undoubtedly 


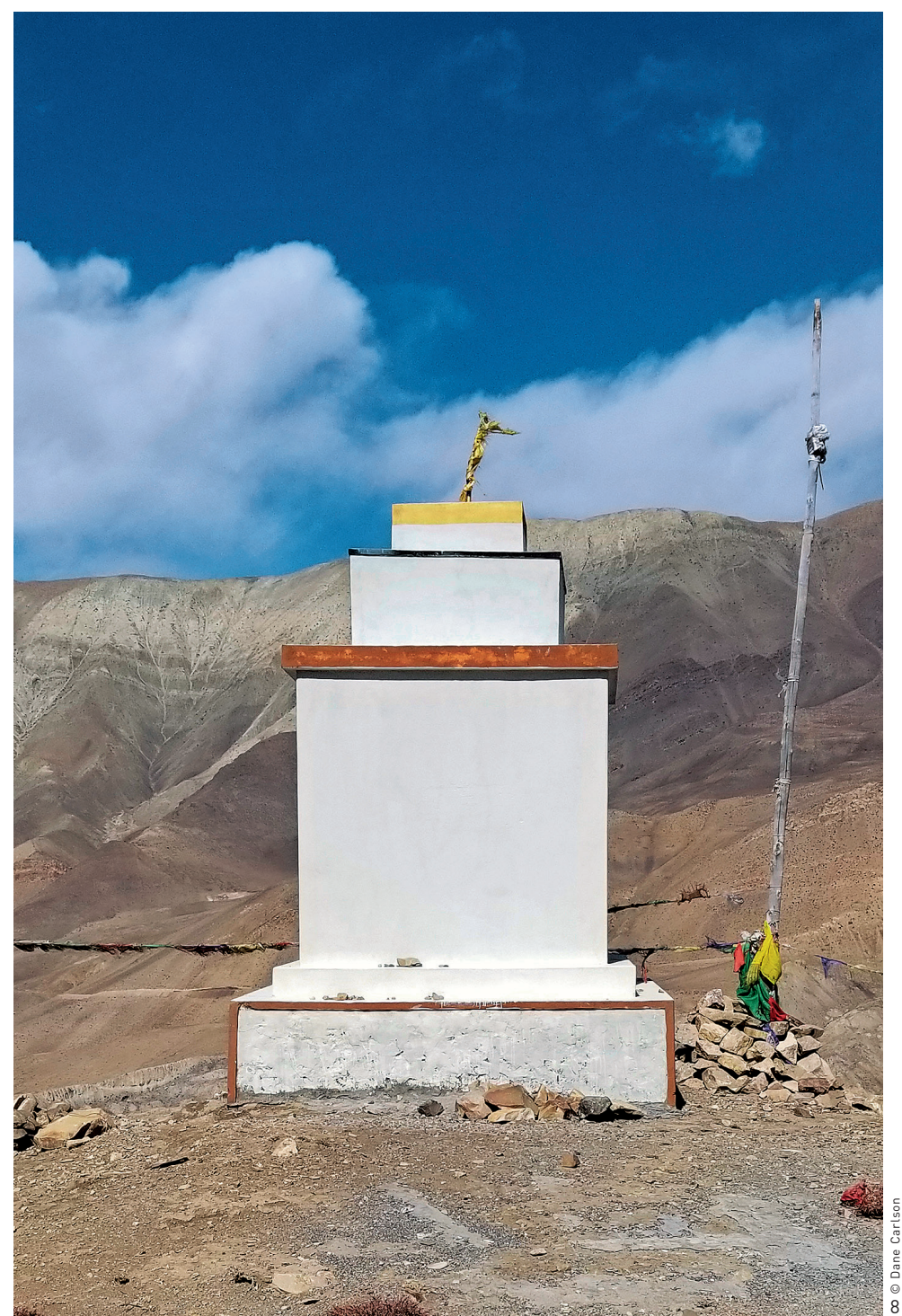

7. 位于帕特克的石墙、 转经筒, 以及曲丹佛 塔。这座佛塔里装满 了由祭品的灰烬制成 的贝壳状小物件。

8. 在开穆卡尔村, 大多 数曲丹佛塔都于 2017 年被拆毁并使用混凝 土重塑。 brings access to life-changing goods and services, the realities are far more complex. Recent research makes it clear that roads exacerbate socio-economic inequality. The landed and wealthy are able to take advantage of new economies, while marginal populations are unable to capitalize in the same way. Instead they are left at the mercies of unreliable infrastructure and transportation and the decay of a previously pervasive system of family networks. In the Muktinath Valley, the road to the popular pilgrimage shrine at Muktinath is now paved. Though it provides easy access to this point, it has created a diverse set of problematic hybridities (Fig. 5). Poorly designed infrastructure causes stormwater from the road to run directly into adjacent apple orchards and significant washout from rain and snowmelt. Goat herders from every village along the road move along or across it, and their livestock is vulnerable to seasonal traffic from buses and jeeps. Spoil from the construction process and scores of empty tar barrels have been simply left on the edge of the road. Aside from a long line of shops and guesthouses, the potential interfaces between the road and what surrounds it are ignored. The intent driving this landscape-making practice is one-dimensional. The result is not.

This piecemeal practice can be reshaped to build upon the potentially generative relationships between continuity and change. Questions must be asked of these potentials before or during the emergence of change, not after. Hybridity must be guided by intentionality, creating new connections between

knowledge, practices, resources, and infrastructure. It can bridge discontinuities that emerge as a result of infrastructural practices, socio-economic disparities, demographic shifts, and climate change. This is the new vernacular: founded in the resources of place, informed by a deep memory and knowledge, responsive to climatic limitations, and adapting to changing realities.

This new vernacular has begun to take distinct new forms in response to change. Small shifts in resource availability, even if provided unintentionally, can have significant impacts on daily life. In the village of Chhyongkar, a 17-year-old goat herder faced the continual problem of having to either descend into a steep gorge for water or wait to return to the village pond at night. After a pipe was installed to bring water to the village, he took advantage of leaks caused by its haphazard installation to create a series of small pools from which his goats could drink (Fig. 6).

In the case of chhorten (stupa) building, this change has taken the form of new material practice. Ritual infrastructures are pervasive throughout Mustang. The most notable are chhortens, which represent many things and take many forms (Fig. 7). Some memorialize the dead or act as registers of a pervasive sacred geography. Others mediate between village boundaries and the realms of deities, though many younger Mustangis are ignorant of these meanings. Boundary chhortens are often accompanied by the figures of the rigsum gonpo, representing the three protectors of Tibetan Buddhism. Chhortens built from adobe and colored with bright clays are beautiful (Fig. 1). Every component of their construction is uniquely local, and construction methods are poetically imprecise. Clay is often painstakingly extracted from cliffs throughout Lower and Upper Mustang, including the red cliffs at Dhakmar. According to legend, the blood of a demoness killed by Guru Rimpoche is the source of this color. The red clay coloring is a symbol of the superiority of Dharmic religion over 
previously dominant shamanist practice. Chhortens act as registers of the passage of time, slumping and running as rain and snowmelt move across their surfaces.

But chhortens are increasingly built from concrete (Fig. 8). This serves largely to lessen the annual burden of remaking and the costs of accompanying ceremonies. Though concrete may be to some extent a less romantic material, it is seen as a new material for a new generation. As the population steadily declines or is replaced by tenant farmers, the knowledge of the purposes, histories, and rituals surrounding each chhorten fades. It also becomes a question of manpower: concrete and storebought paints are simply less maintenance and time intensive. Concrete also provides more effective waterproofing to protect the objects placed inside, such as books and clothing from important lamas or deceased villagers. In Khimkhar, four sets of the rigsum gonpo guard the village at each cardinal direction. In 2017, the mud and stone chhortens were torn down and new concrete figures were built in their place. White, blue, and yellow store-bought paints were applied, which happened to be available. Despite this change, many chhortens maintain their power. They are still regenerated by ritual practices and maintain their protective potency. But it seems inevitable that diminishing knowledge and regenerative practices made obsolete by concrete construction and outmigration will destroy this potency in time. If this loss occurs, it will not be caused only by the use of a new material. It 的放牧庇护所之一。它 最多可容纳5名牧羊人 以及数百只山羊在此地
Batang, one of the primary herding shelters in the rangelands above Thini, houses up to five shepherds and goats during the winter season.

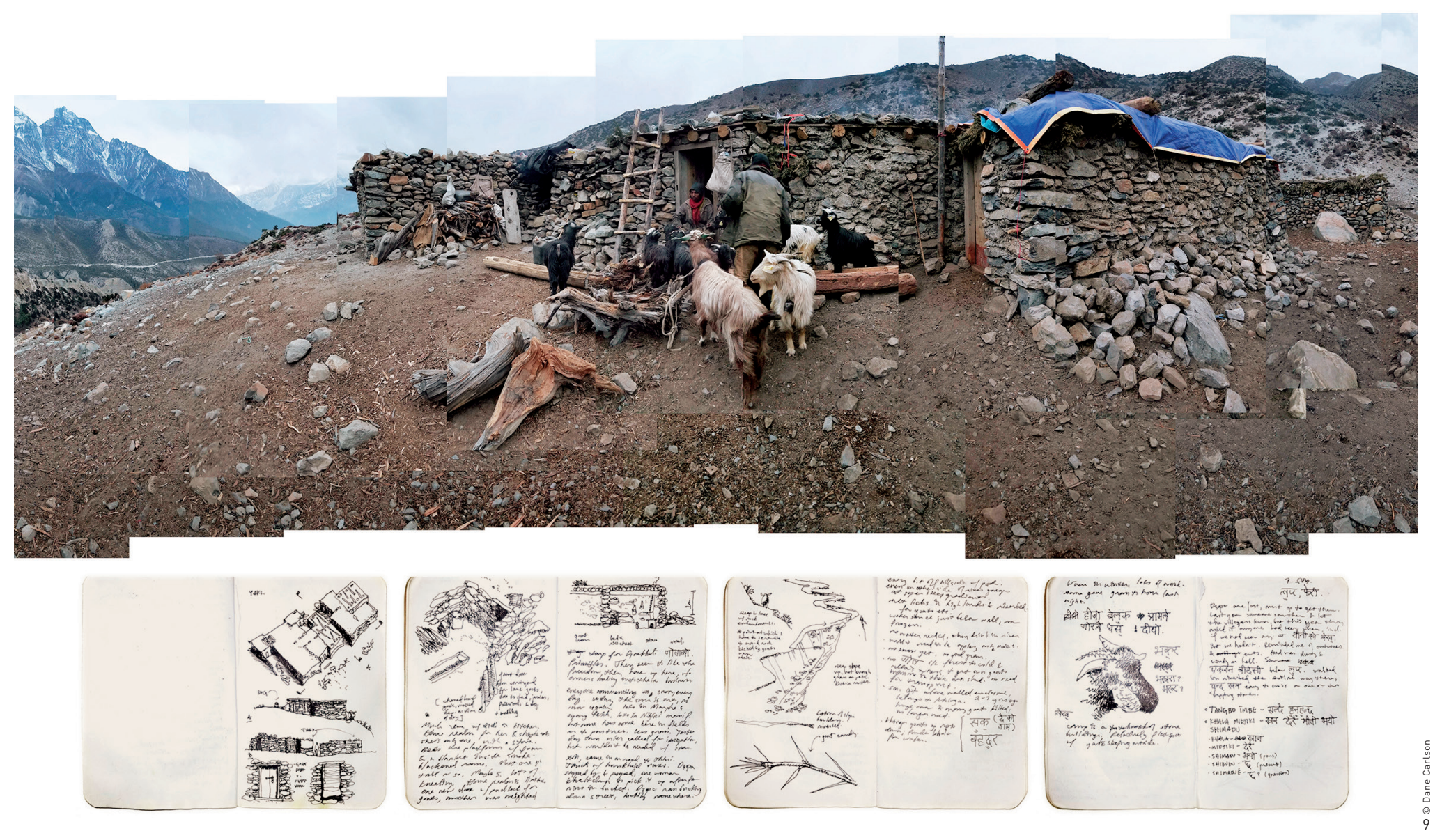




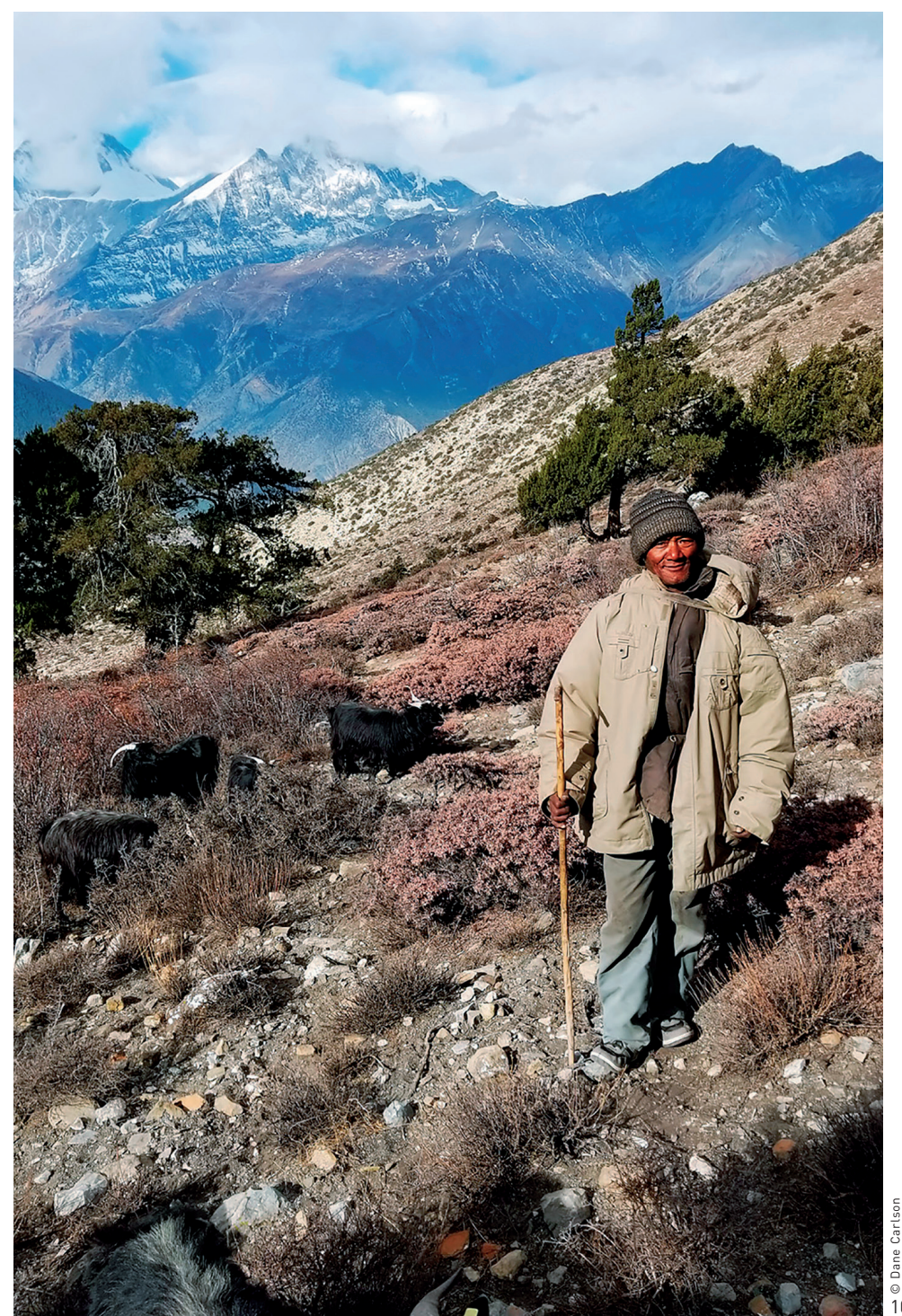

10. 迪曼斯·古隆是来自廊 尔喀地区的古隆族人, 他目前在泰尼村以牧羊

10. Dimansi Gurung, a Gurung from Gorkha district who now lives and works as a shepherd in Thini. will be the loss of knowledge and memory.

The hybridization of continuity and change can be generative. This is especially necessary for marginal populations, particularly in the context of dramatically shifting demographics. As established, the wealthy and landowning families emigrate or build new economic enterprises, while others remain intimately tied to the land and its increasingly dramatic shifts. What little security they possess is shaken by diminishing and increasingly sporadic precipitation. Therefore, designers have the ability and responsibility to act within this landscape, building upon the principles of the new vernacular to shape the landscape in partnership with these people.

Throughout Mustang, livestock remains a significant component of local livelihoods. Herders guide and guard them through seasonal movements across diverse rangelands. They typically spend months in stone shelters scattered throughout village uplands, eliminating the need to spend valuable time moving between villages and high rangeland (Fig. 9). But these herders are typically from other districts, rarely stay in Mustang longer than several years, belong to lower caste groups, and rarely own any of the livestock they are charged with. Their livelihoods are increasingly vulnerable to changes in precipitation patterns and the subsequent reduction of fodder. Though they actively shape the landscape as they guide their flocks, their agency and potential as actors within the landscape are ignored. Within the new vernacular landscape, herders have the capacity to act not only as watchers, but as stewards and shapers (Fig. 10).

This new vernacular is formed by knowledge, meaning, practice, and the physical landscape itself. It remains driven by an intimate knowledge of the moods and faces of the land, the resources it provides, and the changes it undergoes. But this knowledge can grow to encompass a broader body of scientific knowledge, providing herders with the tools to shape practice and infrastructure. As snow and rainfall become more unpredictable, new infrastructures can offset these shifts by constructing microclimates which retain moisture. They can simultaneously provide shade, prevent wind-driven desiccation, form snow banks as water reserves, provide shelter for herders and livestock, and be used as watchtowers for herders guarding their flocks. As grazing practice will likely disappear in response to largescale emigration and increasing costs, these infrastructures can be transformed into new uses. They can promote the growth of fire-ravaged juniper stands or create habitat for the deer hunted by snow leopards, which is the focus of most current conservation efforts. But most importantly, these examples also allow the herders to exercise agency within the landscape.

The emergence of a new vernacular is the continuation of millennia of landscapemaking through adaptive response. It is driven by responses to the complexities of daily life, by the agency of people and their knowledge. In a world where adaptive response and resilient building are increasingly significant, this is a necessary future. LAF

REFERENCES

[1] Jackson, J. B. (2009). Discovering the Vernacular Landscape. New Haven: Yale University Press.

[2] Doherty, G. (2017). Paradoxes of Green: Landscapes of a City-State (p. 32). Oakland: University of California Press. 